rightly insists upon its importance, elaborating it at length in this article. On the other hand, we must not forget that such a south-to-north migration, from a warmer to a colder climate, is an unusual proceeding in the history of mankind.

Returning to the excavations at Sparta, we see from the articles dealing with them how important this phase of the school's work is proving to be. The identification of the site and discovery of the remains of the temple of Artemis Orthia, where the wellknown Spartan flagellation of the boys took place in honour of the goddess, is a great feather in the caps of Prof. Bosanquet, Mr. Dawkins, and their assistants. The discovery of a regular stratum of early votive offerings, chiefly archaic bronzes of the Olympia type, but in some ways more interesting than those, is an important event, as it adds considerably to our knowledge of archaic Greek art, especially in that peculiarly inartistic and philistine place, Sparta and the many inscriptions of Roman date throw light, not only on the flagellation ceremony, but generally on the course of life in Roman Sparta. In publishing these inscriptions, Mr. H. J. W. Tillyard insists in every case on adding a Latin translation, which is perfectly unnecessary, and savours of scholastic pedantry. If we are to have translations, let them be in English if the commentary is English.

We are unable to devote more space to the discussion of the Spartan discoveries, owing to the claims to notice of much other interesting matter in this volume of the "Annual." Also, it is perhaps best to postpone further comment until next year, when the work will have been further advanced.

Of these other articles, all are of interest and many of importance, with the exception of a note on "Boats on the Euphrates and Tigris," which seems hardly appropriate to the "Annual of the British School at Athens," and contains no new information; we have known all about keleks, shahtûrs and kufas, and have compared them with Herodotus, i., I94, since the days of Rawlinson and Layard.

Of the other articles, perhaps Mr. Droop's and Mr. Dickins's are the most "geistreich." Mr. Droop on Cretan geometric pottery is illuminating, and $\mathrm{Mr}$. Dickins's article on "Damophon of Messene" is an example of good archæological criticism, on which the author may be congratulated. The travel articles by Messrs. Dawkins, Wace, Hasluck and others are interesting, as usual, and we welcome a contribution by a native Cretan archæologist, Dr. Xanthoudídes, who speaks our language, and, apparently, writes it as well. Finally, Mr. Traquair contributes to our knowledge of the deeply interesting period of the Frankish domination in the Morea, with an article on the mediæval fortresses of Laconia, which will interest heralds as well as archæologists. H. R. HaLl.

\section{THE FUTURE WATER SUPPLY OF LONDON.}

$\mathrm{I} \mathrm{N}$ an interesting paper on "London's First Conduit System," just published in the Transactions of the London and Middlesex Archæological Society, Dr. A. Morley Davies gives an account of the lines of pipes which were laid in the thirteenth and succeeding centuries to carry water to London from springs in the gravel at Paddington, Marylebone, and other rural districts. At a later date, to meet the growing wants of London, the great engineering effort of the New River was undertaken, and later still deep wells were driven into the chalk, and the Thames was tapped above Teddington Weir by several private companies. The unification of the London waterworks under one comprehensive and representative Board which bought out the old companies is so recent that it is almost surprising to find how soon the organisation of the Board has been perfected and its members set free to consider the tremendous problem of the future water supply of London.

A good many years ago much was heard of the necessity for obtaining a totally new supply of water for London from a pure and distant source which should be beyond the suspicion of impurity and capable of supplying the highest parts of the metropolitan area by gravitation. The sentimental argument that the water companies pumping from the Thames and Lee had to purify a raw material which has sometimes been described as "diluted sewage" is one which cannot fail to appeal to the imagination of every water-drinker, despite the reassuring result of the supreme test-the death-rate of London. But the restrictive activity of the Thames Conservancy and the discovery of the remarkable action on raw water of storage and thorough filtration have robbed the argument of its old force, while the exhaustive bacteriological examination of the raw and filtered water by Dr. Houston and his staff in the Metropolitan Water Board's laboratory has satisfied even those who heartily dislike lowland rivers as a source of water supply that the safeguards in the case of London are adequate to ensure purity.

The sufficiency of the supply is another matter, and on this point the Water Board, after prolonged discussion at two meetings, came to a decision as to their future policy on December 6 . The Works and Stores Committee prepared a careful report reviewing the situation which, after amendment, was adopted. The whole subject of London water supply had been gone into by two Royal Commissions in recent years, one under Lord Balfour of Burleigh in 1892 , the other under Lord Llandaff in 1897 , and the committee's report does not repeat the details elicited by those inquiries. It is noted, however, that the average daily supply to London in $\mathrm{I} 88 \mathrm{I}$ was 143,821 , 000 gallons, or $33^{\circ} 20$ gallons per head for a population of $4,33 \mathrm{I}, 600$, while in $1906-7$ the average daily supply was 225,000 , ooo gallons, or $32 \cdot 84$ gallons per head for a population of $6,85 \mathrm{I}, 000$. Of the present daily supply of $225,000,000$ gallons, 57 per cent. comes from the Thames, and the remainder in nearly equal proportions from the Lee and from wells or springs, the actual figures being :-

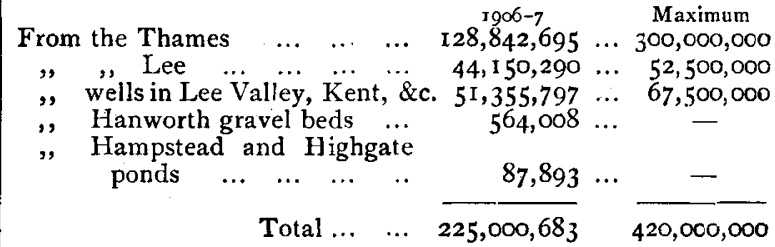

The maximum column gives the figures which the Balfour Commission held to be the greatest average daily yield of the whole district.

The total amount of water which the Board can abstract from the Thames in existing conditions is 228,500 , ooo gallons per day, and even this amount cannot be obtained until additional storage reservoirs have been constructed. The maximum supply to be relied upon from sources other than the Thames is estimated by the chief engineer to the Water Board at 120,000,000 gallons per day, the total available being thus $348,500,000$ gallons per day.

It is estimated that by I94 I the population to be supplied by the Board will be $12,000,000$, and in $196016,286,000$, and, assuming a consumption of thirty-five gallons per head, this means $420,000,000$ 
gallons in I94I, and 570,000,000 gallons in I960. Of the various sources of supply, that from the Thames alone is capable of considerable expansion, and in 1960 it is estimated that $450,000,000$ gallons per day may be taken from that river. In order to admit of this expansion, immense storage reservoirs would require to be constructed; the amount of storage necessary in 1916 would be $6,436,000,000$ gallons, in I94I as much as $27,276,000$, 000 gallons, and in 1960 the prodigious amount of $54,059,000,000$ gallons, the necessary storage increasing at a greater rate than the supply. The chief engineer believes that $450,000,000$ gallons is the limit which could be taken economically from the Thames in any conditions.

The works at present in existence or authorised will suffice for the supply of London until 1917 , and to provide the additional works required at that date it will be necessary to approach Parliament for new powers in rgro. The new scheme which has been definitely adopted as the policy of the board is to develop the supply from the Thames valley, and to trust to that as sufficient for the next fifty years, but at the same time to acquire powers for securing a supplemental source of supply to be utilised when the existing sources can no longer be developed economically. In the report as issued reference is merely made to " a distant source" being necessary fifty years hence, but in the debate the source was referred to plainly as Wales. It is remembered that before the creation of the Metropolitan Water Board the London County Council as water authority developed a scheme for supplying London with water from Wales in competition with the companies, and it was proposed in the debate on the report before the Water Board to proceed forthwith with a Welsh scheme, but a very large majority agreed to endorse the recommendations of the report in this particular. The three important resolutions as amended in another particular and adopted are as follows :-

" (a) That in the opinion of the Board it is desirable to seek Parliamentary powers enabling them to provide additional supplies from the Thames for as long a period as is economically practicable.

"(b) That as the increase in population will eventually render resort to some other source than the Thames watershed imperative, the Board view with great alarm the increasing tendency of authorities throughout the kingdom to appropriate water-supplying areas for their particular use, and in these circumstances desire to urge upon Parliament the necessity for regulating the appropriation of water-supplying areas, so that the needs of the metropolis as well as of other populous places may receive due consideration.

"That a copy of the foregoing resolution be sent to the President of the Local Government Board, and that he be asked to receive a deputation from the Board on the subject; and further, that in the event of such request being granted, the Works and Stores Committee be authorised to make all necessary arrangements with regard to the deputation.

" (c) That it be an instruction to the Works and Stores Committee to prepare and submit to the Board as early as practicable a scheme to give effect to the foregoing resolutions."

The Metropolitan Water Board is the largest and most important water authority in the United Kingdom, being responsible for the supply to one-sixth of the population of the British Isles. The distribution of rainfall, on which water supply depends immediately or ultimately, is, speaking broadly, the inverse of the distribution of population. Taking the part of England and Wales south of the Trent, it may be said that most people live in the Thames valley, while most rain falls in Wales. Much rain falls also on Dartmoor, Exmoor, and in the Lake District, all of them distant and unpeopled places on which the eyes of nearer populations have been turned for some time. It is the custom of Governments to assume control of the distribution of natural treasure and to regulate the pegging-out of claims for hewing out gold or diamonds, and the Water Board now proposes to ask for the extension of this principle to the drawing of water for great communities. The sug. gestion is not new, but it will none the less meet with keen opposition, for the large towns with great and distant water supplies are usually permitted and sometimes compelled by Parliament to sell surplus water to the communities along the track of their aqueducts, and hence municipal foresight may involve taking thought also for possible interference with spheres of interest.

It is interesting to compare the proposed appeal to Government to keep a place in the struggle for water-yielding grounds for the supply of London half a century hence with the arguments employed by Mr. Urquhart A. Forbes in a paper on "The Water Supply of the United Kingdom "' in the October number of the Quarterly Review. Mr. Forbes urges the appointment of a central water board for the country with subordinate watershed boards in order to check the depredations of the great towns on the upper reaches of rivers, and to ensure the maintenance of the lower streams in a condition fit for navigation and fishing. It must not be forgotten that rivers not only water the land, but drain it as well, and to the mind detached from all municipal or commercial schemes it appears self-evident that the same channel should not be required to act both as an aqueduct and as a sewer. On the other hand, it is an acknowledged fact that the insertion of a properly proportioned artificial lake in the upper waters of a river benefits that river by checking floods in wet weather and maintaining a good flow in dry weather, while it enables a permanent and pure supply to be drawn for the uses of a distant population. To the scientific mind the surprising thing is that steps have not been taken long ago to gauge the flow of all the rivers in the country and to establish rain gauges in remote and uninhabited places where the treasure of the heavens descends in fullest amount. Not until this has been done can the alliterative dictum of Mr. John Burns-"Rain to the rivers, sewage to the sea "-become an effective mandate.

\section{NOTES.}

The Nobel prizes, of the value of nearly $7700 l$. each, were presented at the Academy of Sciences at Stockholm on Tuesday. In science, the prizes were awarded as follows :-physics, Prof. Michelson, University of Chicago; chemistry, Prof. Buchner, University of Berlin; medicine, Dr. Laveran, Pasteur Institute, Paris.

The Glasgow Corporation has decided to confer the freedom of the city on Lord Lister.

A TELEGRAM from Largs states that Lord Kelvin has not been well for more than a fortnight, and has been confined to his bed. His condition on Tuesday night had improved.

Mr. J. D. Rockefeller has just given an additional sum of more than $520,000 l$. to the Rockefeller Institute for Medical Research in New York, to be held as an endowment the income of which is to be used at the discretion of the management.

THE death is reported, in his seventy-ninth year, of Dr. Asaph Hall, professor of astronomy at Harvard since 1895 . Prof. Hall received an elementary-school education in his No. 1989, vOL. 77] 